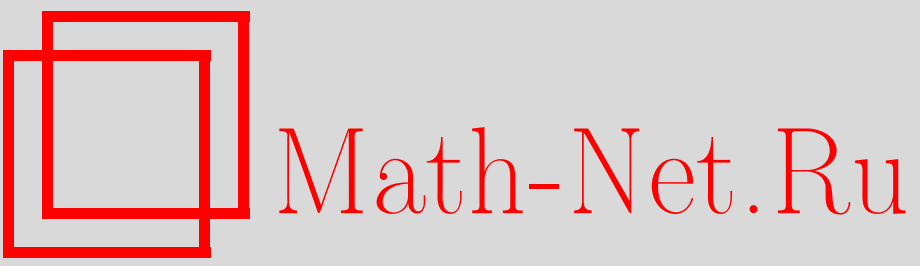

Н. Л. Гордеев, А. Л. Вернер, А. Е. Евсеев, С. И. Кублановский, И. С. Понизовский, А. В. Яковлев, Евгений Сергеевич Ляпин (некролог), УМН, 2005, том 60, выпуск 2, 143-144

DOI: https://doi.org/10.4213/rm1408

Использование Общероссийского математического портала Math-Net.Ru подразумевает, что вы прочитали и согласны с пользовательским соглашением

http: //www. mathnet.ru/rus/agreement

Параметры загрузки:

IP : 3.82 .47 .9

26 апреля 2023 г., 06:21:26 


\section{ЕВГЕНИЙ СЕРГЕЕВИЧ ЛЯПИН}

13 января 2005 года на 91-м году жизни скончался Евгений Сергеевич Ляпин, заслуженньй деятель науки Российской Федерации, доктор физико-математических наук, профессор кафедры алгебры РГПУ им. А.И. Герцена.

В годы войны, находясь в блокадном Ленинграде, Евгений Сергеевич работал в Главной геофизической обсерватории по военной тематике. За эту работу ему было присвоено звание профессора по одной из физических специальностей.

В 1945 году Е. С. Ляпин защитил докторскую диссертацию по алгебраической тематике и с 1946 года по 1982 год он - бессменный заведующий кафедрой алгебры Педагогического университета им. А. И. Герцена. В последние годы вел активную творческую работу: руководил работой аспирантов, был руководителем известного научного семинара по теории полугрупп в Санкт-Петербурге.

Евгений Сергеевич - ученый с мировым именем. Его главной научной заслугой является формирование и развитие одной из важных ветвей современной алгебры

- теории полугрупп. Им разработаны основные, фундаментальные понятия этой теории, издана первая в мировой литературе монография по этому направлению - книга "Полугруппы", которая способствовала интенсификации развития теории полугрупп в нашей стране и за рубежом. В последние годы Е. С. Ляпин разработал еще одно новое направление современной алгебры - теорию частичных алгебраических операций и выпустил в свет монографию по этому разделу алгебры.

Под руководством Е.С. Ляпина было подготовлено большое количество кандидатов наук. Многие отечественные и зарубежные алгебраисты неизменно находили поддержку и помощь Евгения Сергеевича. Ученики и последователи Евгения Сергеевича работают во многих городах России и других стран.

Работая на факультете математики Педагогического университета им. А. И. Герцена, Евгений Сергеевич внес большой и ценный вклад в разработку новых учебных планов и программ по углублению математической подготовки будущих учителей. Его лекции всегда отличались четкостью, глубиной, насьщенностью новыми идеями.

Евгений Сергеевич - автор ряда учебных пособий по алгебре, которые широко используются студентами в нашей стране.

Большая общественная работа Е. С. Ляпина всегда была связана с совершенствованием педагогического просвещения в нашей стране и в ряде других стран. За свою работу Евгений Сергеевич награжден орденами и медалями. Ему присвоено звание "Заслуженный деятель науки РСФСР" и звание "Почетньй профессор РГПУ им. А. И. Герцена". 
Евгения Сергеевича хорошо знали и ценили математики в нашей стране и за рубежом. Принципиалность, научная добросовестность, чуткость всегда служили вдохновляющим примером для всех, кто имел с ним дело.

Память о крупном ученом, замечательном педагоге и научном руководителе навсегда останется в сердщах его близких, коллег и соратников.

Н. Л. Гордеев, А.Л. Вернер, А.Е. Евсеев, С.И. Кублановский, И. С. Понизовский, А.В. Яковлев 